\title{
The Students' Motivation Regarding the Improvement of Their Fitness Through the Curricular Options of the Physical Education and Sports Study Program
}

\author{
Dobrescu Tatiana ${ }^{1 *}$ \\ 1"Vasile Alecsandri" University of Bacau, 157, Calea Marasesti, 600115, Romania
}

Keywords: motivation, students, fitness, curricular options.

\begin{abstract}
The aim of this research was to discover, through a questionnaire, the elements that influence the students' motivation to improve their fitness, and seeing the sources that have the most positive results. In this sense, a sociological study was organized between 20152017 on a group of 64 second year undergraduate Physical Education and Sports students (PES), of the Faculty of Movement, Health and Sports Sciences of Bacau. The points given by the respondents to each item offered us the possibility to analyze the motives within the 5 groups of needs identified by the authors: physiology, security, social contacts, esteem, consideration, and self-accomplishment. These results prove that the second year PES students are aware of the important role played by muscle training, team spirit, communication and understanding with the people around them, being convinced of the effects of the socialization and relating in their everyday life and their future career.
\end{abstract}

\section{Introduction}

The concept of fitness refers to "that physical state that allows the individuals to conduct their lives (professional activity and leisure time) as well as extra effort in optimal conditions without signs of fatigue" (Clarck, 1976).

Experts such as Orunaboka and Ogulu (2011), Grosu, Popovici and Mihaiu (2010), Epuran, (2005) have described the main components of fitness as: aerobic capacity, muscle power and endurance, flexibility, body composition, and nutrition. According to Corbin and Lindsey (1983), fitness is a set of attributes through which the individual faces the physical and functional demands in everyday activities, being dependent on the anatomical and psychological condition.

In light of the growing popularity of fitness activities, everyone wants to believe that they can look like Hercules, but this happens only when people have fundamental motivations. Visible results appear quickly when dealing with a special program, but a defined goal is reached only as a result of a rigorous training

*E-mail: tatianadobrescu2002@yahoo.com 
and diet regime.

The practice of fitness programs and the association with a routine exercise can lead to satisfactions, giving a feeling of fulfillment and many benefits for health, and the birth of certain needs and motivations to begin and to continue these preoccupations can be challenging. (A.C.S.M., 2015)

The right load of the physical tasks activates the physiological processes of the body, stimulates the adaptation abilities and increases the functional reserves of the body. The sedentary lifestyle or the physical load that does not correspond to the person's physical abilities can lead to health problems and can even negatively affect the parameters of the physical and functional development. (Jansone \& Krauksts, 2005). Many researchers in their studies mention among the risk factors of lack of exercise and lack of concern for one's own fitness, other two dangerous actors in modern society - the sedentary lifestyle (Gutiérrez-Fisac, RoyoBordonada \& Rodriíguez-Artalejo, 2006) and obesity (Gutiérrez-Fisac, Regidor, Banegas \& Rodriíguez-Artalejo, 2005).

The benefits of exercise are scientifically proven by many experts. Regular exercise helps reducing the risk of breast cancer by $39 \%$, colorectal cancer by $26 \%$, of a stroke by 25\%, and of diabetes by 34\%. (Haskell et al., 2007).

Through the diversification and dosage of the physical effort, through the increase of regular volume and intensity of the drills, the functional skills of the body together with the development level of the physical abilities increase during the training process (Jansone \& Vazne, 2009).

One benefit is the application of physical activity programs that would promote among young people drills developing the endurance and the flexibility (Alonso-Fernández, Gutiérrez-Sánchez \& Pino-Juste, 2012).

Having a nice body should be the goal of every young person, and the training process is about setting priorities for compound drills, mostly performed traditionally. The social environment formed of relationships and social values influences young people to go to the gym, forming their ideas about shaping their body. The effects of exercising lead to ensuring an optimal fitness, but also a great psychological and cognitive state, a fact highlighted in several studies conducted by Fedewa and Ahn (2011), Keeley and Fox (2009).

Also, one's lifestyle, age, gender, socio-economic status are other factors that can have moral and aesthetic values, such as tenacity, perseverance, vitality, physical beauty, trustworthiness, mental balance, love for work, engagement, etc. (Dobrescu, 2008a; Grosu, 2012).

Within the physical values, the emergence of interest, of the desire to achieve, of the human interrelation between colleagues or with the coach, is no longer a disinterested act. The complete form of existence and development of the motivating factors is found the best within the training concepts that facilitate the stimulation of overcoming oneself and reaching high goals in order to optimize 
one's fitness. "Beside the cognitive skills, the general motivation for top performance can be looked at as a second feature relevant for professional success". Sometimes the motivation for top performance is believed to be the most important source for professional top performance (Atkinson, 1978). Exercising is done by considering the various attractions and ambitions in having the desired fitness, ambitions that can be motivated by coaches, instructors, or other, more experienced, colleagues.

Starting from the identified premises, this research was chosen to study the perception of the Physical Education students concerning their interest regarding exercising within the curriculum of Physical Education and Sports.

A sociological approach can identify important landmarks regarding the students' groups of motives and needs about the improvement of their fitness through bodybuilding or aerobic gymnastics.

\section{Material and methods}

The problem of students' motivation must be understood through the efforts of motivating them into a certain direction, more significant if the teacher - student or student - student relationship is considered to be one of collaboration, sharing the same feelings, goals, and aims. Thus, the motivational interventions that do not respect one's beliefs regarding the practice of a sport in order to improve one's fitness can produce effects on short term, which over a longer period of time can fail. Although it is believed that good fitness is due only to genetics, it must be admitted that a determining role in reaching the set goals is played by the students' motivation to prepare for and participate in the optional improvement disciplines.

Starting from the statement by Roşca (1966, p. 439), that without knowing the psychological particularities, one cannot organize and direct their perception, conduct, attention, nor one can predict the degree of understanding and assimilation of an instructional process, this study was initiated, concerning the optimization of fitness during the teaching process of the future teachers.

The aim of this research was to discover, through a questionnaire, the elements that influence the students' motivation to improve their fitness, and seeing the sources that have the most positive results.

In this sense, a sociological study was organized between 2015-2017 on a group of 64 second year undergraduate Physical Education and Sports students, of the Faculty of Movement, Health and Sports Sciences of Bacau.

This research started from the hypothesis stating that the identification of a hierarchy in the groups of needs and motives of the PES students offers the possibility to direct them toward the improvement of their fitness through the optional courses of bodybuilding or aerobic gymnastics.

The conditions of the research were optimal, and the subjects chose unconditionally to go through the stages of the research.

The research methods were: the study of the professional literature, the observation, the questionnaire-based inquiry, the statistical-mathematical method 
and the graphical representation method.

The inquiry was based on the "professional motivation questionnaire," adapted by Roco (2001, pp. 214-215), based on Bazin. Through this validated instrument one can objectively assess the needs and motives that form the basis for the conscious involvement of the students in the disciplines envisaging the improvement of their fitness, by ranking the 35 assertions in the order of their given importance.

The points given by the respondents to each item offered us the possibility to analyze the motives within the 5 groups of needs identified by the authors: physiology, security, social contacts, esteem, consideration, and selfaccomplishment (Table 1).

Table 1. Groups of motives and needs

(adapted by Roco, based on Bazin, 2001, pp. 214-215)

\begin{tabular}{ccl}
\hline $\begin{array}{c}\text { No. need } \\
\text { groups }\end{array}$ & $\begin{array}{c}\text { No. of questions corresponding to the } \\
\text { needs }\end{array}$ & \multicolumn{1}{c}{ Name of need group } \\
\hline I. & $3,6,7,17,19,33,35$ & Physiological \\
II. & $1,9,16,18,22,31,34$ & Safety \\
III. & $2,5,10,11,20,27,32$ & Social (human) contacts \\
IV. & $4,8,13,21,23,24,29$ & Esteem, consideration \\
V. & $12,14,15,26,28,30,25$ & Self-accomplishment (fulfillment) \\
\hline
\end{tabular}

According to this instrument of sociological analysis, the normative evaluations have led to judgments of value and the assessment of the students' motivational psychological availability for performing sports that would influence their fitness.

\section{Results and Discussions}

In order to emphasize the needs and motives on which the manifestation of the target group is based, the results recorded in the 5 groups were interpreted taking into account the average, maximum, and minimum group values (Table 2, Fig. 1).

Table 2. Centralizer of the statistical results of the target group for the motivation questionnaire

\begin{tabular}{lccccc}
\hline \multirow{2}{*}{ Statistical markers } & \multicolumn{5}{c}{ Groups of motives and needs } \\
\cline { 2 - 6 } & Fz & Cs & Rs & S & Sc \\
\hline Arithmetical mean & 106.17 & 113.76 & 129.45 & 138.43 & 142.18 \\
Standard deviation & 23.95 & 22.49 & 21.70 & 22.69 & 32.11 \\
Maximum value & 164 & 152 & 163 & 181 & 188 \\
Minimum value & 72 & 65 & 96 & 102 & 73 \\
\hline
\end{tabular}

Legend: Physiology (Ps), Human social contacts (Sc), Self accomplishment (Sa), Safety (S), Esteem, consideration (Ec). 
The results recorded for the 5 groups of needs and motives identified in the target group's perception were analyzed and interpreted taking into account the average, maximum, and minimum values, related to the level of the group.
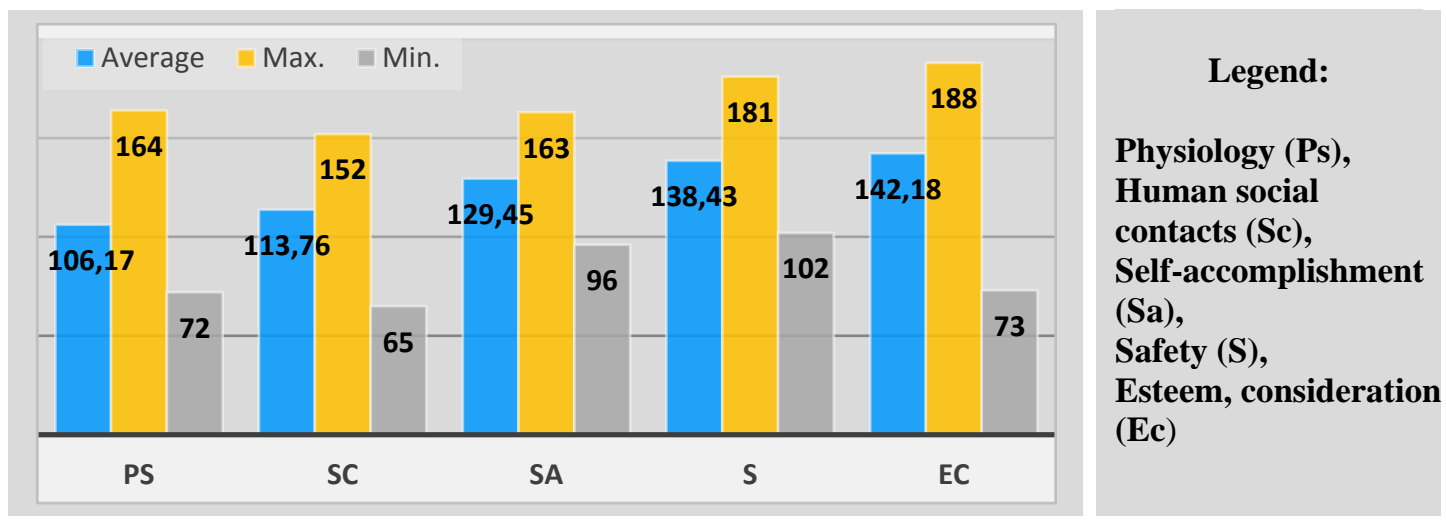

Figure 1. The average, maximum, and minimum results of motivation

The standard deviation (Table 2, Fig. 2) for the 5 groups of identified motives recorded values between 32.11 (Ec) and 21.70 (Sa) points, values that are considered to be high, proving a low homogeneity degree of the inquired group, a normal aspect.

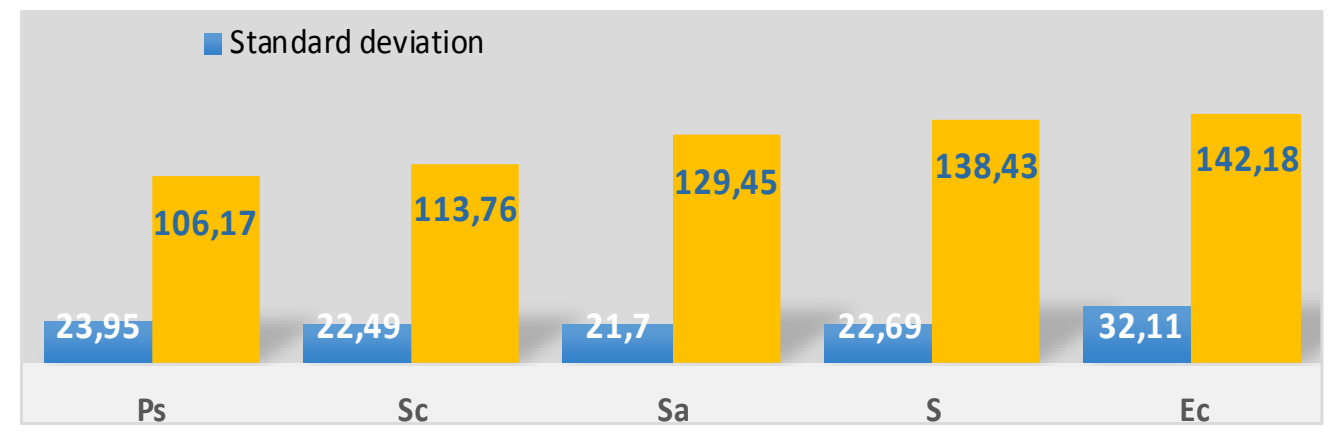

Figure 2. The standard deviation results of the motivation on need groups

The physiological group of needs and motives was situated very high in the preferences of the inquired students, with an arithmetical mean of 106.17 points, a minimum value of 72 points and a maximum value of 164 points. (Table 2, Fig. 1) The difference between the average and minimum value is of 34.17 points, smaller than the one between the maximum and the average value, of 57.82 points.

The physiological motives are in the first position, and the lower values of these items prove that, for the respondents, the morpho-functional effects of the activities for the optimization of their fitness are a priority. 
The assessment of this group of tendencies considered the role played by the rigorous and rationalized training programs, the advantages of dosing the effort and the possibility to alternate it with resting breaks. To this it is added the assessment of good working conditions, the attractiveness of training programs by ensuring the technical framework for overcoming the athletes' own efforts. Also, there are considered the effects of these programs on the optimization of the subjects' fitness, the influence of the functional parameters, morphological body shaping, which are useful aspects to capitalize on in their career as future teachers.

The standard deviation (Fig. 2) in this group of motives has a value of 23.15, which shows a low degree of homogeneity in the target group.

In the order of their values, there are the motives and needs regarding social contacts, with an average value of 113.76 points, a maximum value of 152 points, and a minimum value of 65 points. The difference between the average and minimum value is of 48.76 points, higher than the one between the maximum and the average value, of 38.23 points. (Table 2, Fig. 1)

One can say that for the students in the studied group what matters is the social framework, the human contact during the training, with implications in the permanent modification and adaptation to the always changing situations, to the work group and environment.

These results prove that the young people in the target group appreciate the spirit of collaboration, communication and understanding with their colleagues, created during bodybuilding or aerobic gymnastics training, which is a very important aspect in the professional training process. Considering also other aspects in this group of motives, it results that the subjects appreciate the institution that trains them, it having an image and a prestige acquired through the quality of the training process of its graduates. Also, the subjects are motivated by the presence of specialists who coordinate the disciplines in the curriculum, who are competent, professional, and are nationally acclaimed. They perceive the importance of participating in these forms of exercise through the influence of other participants who help them overcome the barriers of an intense effort.

The standard deviation (Fig. 2) in this group of motives recorded a value of 26.28, which shows a low degree of homogeneity in the studied group.

In the third place of the inquired students' preferences is the selfaccomplishment group, with an average value of 129.45 points, a maximum value of 163 points, and a minimum value of 96 points (Table 2, Fig. 1). The difference between the average and minimum value is of 33.45 points, smaller than the one between the maximum and the average value, of 33.54 points, observing a tendency toward the average.

This position within the 5 groups of motives and needs supports the students' perception on the role of creativity and adaptation during training activities. They want to meet their need to improve their fitness by taking responsibility in what they are doing, being capable of assessing the actions' possibilities to stimulate their interest, of self-evaluating and self-assessing their own activities. The respondents are convinced of the importance of the curricular goals and they 
appreciate the opportunities for a responsible activity involving the stimulation of effort, the increase of effort capacity and the development of personality.

The standard deviation (Fig. 2) in this group of motives recorded a value of 18.94, which shows the highest degree of homogeneity in the studied group.

The group of motives derived from the need for safety has a smaller importance in the pupils' motivations, recording an average value of 138.43, with a maximum value of 181 and a minimum value of 102. (Table 2, Fig. 1). The difference between the average and minimum value is of 35.43 points, smaller than the one between the maximum and the average value, of 43.56 points.

In regards to this group of needs, the subjects manifested concern for an imposed activity, for the safety of the gym, and for the uncertain possibility of a permanent guidance. The training activity is undervalued, in the sense that they feel they are capable of self-training based on their knowledge and skills.

The standard deviation (Fig. 2) in this group of motives recorded a value of 26.31, which shows a low degree of homogeneity in the subjects.

The last position is taken by the group regarding the formation of the traits esteem and consideration, with an average value of 142.18 points, a maximum value of 188 points, and a minimum value of 73 points. (Table 2, Fig. 1). The difference between the average and minimum value is of 69.18 points, higher than the one between the maximum and the average value, of 45.81 points.

From the subjects' answers it can be concluded that the students are not preoccupied by the possibility of conducting a quality training session, with clearly defined tasks, which requires their attention. They are reticent when it comes to the indications regarding the optimized training, which they do not perceive as useful, miscalculating the effort. At the same time, the subjects expressed worries about not having the freedom and independence to perform their favorite drills.

The standard deviation (Fig. 2) in this group of motives recorded a value of 38.21 , which shows the lowest degree of homogeneity in the studied group of subjects.

\section{Discussions}

The understanding of the subjects' mental structure through the sources that can motivate them the most to exercise creates the possibility for them to choose based on increasing their motivation to participate in the training programs and their interest for improving their fitness. The physiological reasons are ranked first and prove that for the subjects the morpho-functional effects of the training process are a priority, appreciating the good working conditions, the attractiveness of the training sessions by ensuring certain dynamic alternatives and favoring overcoming their own efforts.

The final results of the research allow the possibility for the students to express their motivation toward both sports that play a fundamental role in optimizing their fitness. The certitude of this supposition can however be influenced by other subjective factors. 
A study by Parish and Treasure (2003) observed the perceptions of the motivational climate on the situational motivation regarding the behavior toward exercise in pupils. The results of a hierarchical regression analysis revealed the type, the perceived ability and the perception of the mastery climate, explaining a significant quantity of exercise variation. The authors suggest that the promotion of a motivational climate directed toward mastery in physical education will stimulate the situational motivation determined by the self and by physical activity.

In identifying the motivations and the perceived importance of certain participation factors in martial arts in Great Britain, the results have indicated the following order according to the expressed needs and motivations: 1-affiliation; 2friendship; 3-fitness; 4-reward/ status; 5 competition; 6-situational development and 7-skill development. (Jones, Mackay, \& Peters, 2006).

The policies orientated toward increasing the number of hours and ensuring optimal conditions for the development of physical education in schools contained certain projects that constituted important factors in creating favorable infrastructure conditions, offering accessibility from an organizational standpoint. In researching this phenomenon, Solmon (2015) emphasizes that these tendencies are not enough to solve the problems related to the lack of exercise in children and young people. One must take into consideration the psychological factors that influence the orientation of people's preoccupations and their decision to exercise. It is essential for the exercise experts to determine the people's convictions and motivations regarding the importance of exercise programs, of their benefits on one's helath, promoting an active lifestyle in children and teenagers.

\section{Conclusions}

In trying to find the best options to determine what motivates the subjects, this research constitutes an important contribution in identifying their motivation for improving their fitness, useful for their training as future specialists.

These results prove that the second year PES students are aware of the important role played by muscle training, team spirit, communication and understanding with the people around them, being convinced of the effects of the socialization and relating in their everyday life and their future career.

Within the 5 groups of motives and needs it can be identified the subjects' perception regarding the possibilities of stimulating their interest, creative role, and adaptation during training, assessing their own activities.

They are convinced of the importance of the curricular goals proposed in the class chart and appreciate the opportunities for a responsible activity involving the stimulation of effort, the increase of effort capacity and the development of personality.

At the end of the research, it can be observed that the hypothesis stating that the identification of a hierarchy in the groups of needs and motives of the PES students offers the possibility to direct them toward the improvement of their fitness through the optional courses of bodybuilding or aerobic gymnastics, has been confirmed. 


\section{References}

1. ATKINSON, R.L., \& HILGARD ER. (2005). Introducere în psihologie, Ed. a XIV-a, Bucharest: Editura Tehnică, Romania;

2. ALONSO-FERNÁNDEZ, D., GUTIÉRREZ-SÁNCHEZ, Á., \& PINOJUSTE, M. (2012). Health-related physical condition variables in university students. Journal of human sport \& exercise, 7(1): 331-340;

3. AMERICAN COLLEGE OF SPORTS MEDICINE. (2015). https://www.acsm.org/docs/default-source/brochures/finding-yourmotivation-for-exercise.pdf

4. CLARKE, H.H. (1976). Application of measurement to health and physical education. (5th Ed.). Princeton;

5. CORBIN, C., \& LINDSEY, R. (1983). Fitness for life. Glenview, IL: Scott, Foresman.

6. CUCEU, A.D., CUCEU, M.D., \& GROSU, E.F. (2014). The relationship between exercices and self - esteem, Studia UBB Education Artis Gymn, 59 $(L I X)(2): 19$ - 32;

7. DOBRESCU, T. (2008a). Gimnastica aerobică - o alternativă pentru un nou stil de viaţă al adolescentelor, Iaşi: Editura Pim, Romania;

8. DOBRESCU, T. (2008b). Gimnastica aerobică - strategii pentru optimizarea fitnessului, Iaşi: Editura Pim, Romania;

9. EPURAN, M. (2005). Metodologia cercetării activităţilor corporale, Bucharest: FEST, Romania;

10. FEDEWA, A.L., \& AHN, S. (2011). The Effects of Physical Activity and Physical Fitness on Children's Achievement and Cognitive Outcomes, Journal Research Quarterly for Exercise and Sport, 82 (3): 521-535;

11. GROSU, E.F., POPOVICI, C., \& MIHAIU, C. (2010). Locul si rolul fitnessului in stiinta sportului, Cluj- Napoca: Edit. G.M.I.;

12. GROSU, E.F. (2012). Gimnastica aerobicăa, Vol I colecţia "Programe de stilare corporală", ed. a II - a, Cluj - Napoca: Edit. G.M.I.;

13. GUTIÉRREZ-FISAC, J., ROYO-BORDONADA, A.M., \& RODRIÍGUEZARTALEJO, F. (2006). Health-risks associated with western diet and sedentariness: the obesity epidemia. Gac Sanit., 20 Suppl1: 48-54;

14. GUTIÉRREZ-FISAC, J., REGIDOR E., BANEGAS, J.R., \& RODRÍGUEZARTALEJO, F. (2005). Prevalence of obesity in the Spanish adult population: 14 years of continuous increase, Med Clin (Barc), 124: 196-197;

15. HASKELL, W.L., LEE, I.M., PATEU, R.R., POWELL, K.E., BLAIR, S.N., FRANKLYN, B.A. et al. (2007). Physical activity and public health: updated recommendations for adults from the American College of Sports Medicine and the American Heart Association. Med Sci Sport Exer., 39(8):1423-1434; 
16. JANSONE, R., \& KRAUKSTS, V. (2005). Sporta izglìtības didaktika skolā. Rīga: RaKa, 336 p.

17. JANSONE, R., \& VAZNE, Z. (2009). Individualised Physical Condition as Means to Promote Students' Health in Long Term Period, Problems of education in the 21st century, 11;

18. JONES, G.W., MACKAY, K.S., \& PETERS, D.M. (2006). Participation motivation in martial artists in the West midlands region of England, $J$ Sports Sci Med. 1(5)(CSSI): 28-34;

19. KEELEY, T.J.H., \& FOX, K.R. (2009). The impact of physical activity and fitness on academic achievement and cognitive performance in children, Journal International Review of Sport and Exercise Psychology 2(2):198-214;

20. ORUNABOKA, T., \& OGULU, C.B. (2011). Analysis of physical fitness of female undergraduate students of education management, University of Port Harcourt, Academic Research International, 1(1): 199-205;

21. PARISH, L.E., \& TREASURE, D.C. (2003). Physical activity and situational motivation in physical education: influence of the motivational climate and perceived ability, Research Quarterly for Exercise and Sport 74.2: p. 173(10);

22. ROCO, M. (2001). Creativitate şi inteligenţă emoţională. Iaşi: Editura Polirom, Romania;

23. ROŞCA, A. (1966). Psihologie generală, Bucharest: Editura Didactică și pedagogică, Romania;

24. SOLMON, M.A. (2015). Optimizing the role of physical education in promoting physical activity: a social-ecological approach, Res Q Exerc Sport, 86(4): 329-37.

\title{
Motivația Studenților privind Optimizarea Condiției Fizice prin Prisma Opțiunilor Curriculare ale Programului de Studii Educatie Fizică și Sportivă
}

\author{
Dobrescu Tatiana ${ }^{1}$ \\ 1"Vasile Alecsandri" University of Bacau, 157, Calea Marasesti, 600115, Romania
}

Keywords: motivație, studenți, condiție fizică, opțiuni curriculare.

\begin{abstract}
Scopul cercetării este de a realiza, prin aplicarea unui chestionar, identificarea elementelor care influenţează motivarea studenților în practicarea fitness-ului și descoperirea surselor de trebuinţe care acţionează cel mai bine asupra celor angrenați în această activitate. În acest sens am organizat un studiu sociologic în perioada 2015 - 2017 pe un lot de 64 de studenți din anul II de la Facultatea de Științe ale Mișcării și Sportului și Sănătății din Bacău, programul Educație Fizică și Sportivă. Punctele alocate de respondenţii cercetării pentru fiecare item au oferit posibilitatea valorizării motivelor încadrate în cele 5 grupe:
\end{abstract}


trebuințe fiziologice, securitate, contacte sociale umane, stimă, consideraţie şi realizare de sine. Aceste rezultate demonstrează că studnții anchetați sunt conștienți de rolul activităților din cadrul pregătirii musculare, de dezvoltarea spiritului de colaborare, comunicare și înţelegere cu cei din jur, fiind convinși de efectele calităților de socializare și relaționare în viața de zi cu zi și în viitoarea carieră.

\section{Introduction}

Conceptul de fitness se referă la ,acea condiţie fizică a individului care permite desfăşurarea vieţii (activitatea profesională şi petrecerea timpului liber) precum şi solicitarea suplimentară în condiţii optime fără semnale de oboseală" (Clarck, 1976)

Specialişti precum Orunaboka and Ogulu (2011), Grosu, Popovici and Mihaiu (2010), Epuran (2005), au descris principalele componente ale condiţiei fizice ca fiind: capacitatea aerobică, puterea şi anduranţa musculară, flexibilitatea, compoziţia corporală şi nutriţia. După Corbin and Lindsey, (1983) fitness-ul desemnează un set de atribute prin care individul face faţă solicitărilor fizice şi funcţionale din activităţile cotidiene, fiind dependent de condiţia sa anatomică şi psihologică.

În lumina popularităţii crescânde a disciplinelor de tip fitness, toți vor să creadă că pot ajunge să arate ca Hercule, asta doar dacă lucrezi cu motivații fundamentale. Rezultatele vizibile apar repede atunci când ne aflăm pe parcursul unui program special, dar atingerea unui aspect visat şi definit apare doar în urma unui regim riguros de antrenament şi alimentaţie.

Exersarea programelor de modelare a fitness-ului și asocierea cu un exerciţiu de rutină poate să ducă la satisfacții, oferind un sentiment de împlinire și multe beneficii pentru sănătate, iar nașterea unor trebuințe și motivații de a începe și de a continua ritmic aceste preocupări, poate fi o provocare. (A.C.S.M., 2015)

Încărcătura adecvată a sarcinii fizice activează procesele fiziologice ale organismului, stimulează abilitățile de adaptare și sporește rezervele funcționale ale corpului. Stilul de viață sedentar sau sarcina fizică care nu corespunde abilităților fizice ale omului poate duce la probleme de sănătate și chiar poate afecta negativ parametrii dezvoltării fizice și funcționale. (Jansone \& Krauksts, 2005). Din studiile efectuate mulți cercetători enumeră printre factorii de risc ai lipsei de activitate fizică și a grijii pentru optimizarea condiției fizice, alţi doi flageli periculoși ai societăţii moderne, sedentarismul (Gutiérrez-Fisac, Royo-Bordonada \& Rodriíguez-Artalejo, 2006) și obezitatea (Gutiérrez-Fisac, Regidor, Banegas, \& Rodriíguez-Artalejo, 2005).

Beneficiile activităţii fizice sunt demonstrate ştiinţific de mulți specialiști. Fitness-ul practicat în mod regulat ajută la scăderea riscului de a dezvolta cancer de sân cu $39 \%$, cancer colorectal cu $26 \%$, riscul unui atac cerebral cu $25 \%$ şi de diabet cu 34\%. (Haskell et al., 2007).

Prin diversificarea și proporționarea efortului fizic, prin creșterea volumului obișnuit și a intensității exercițiilor, calitățile funcționale ale corpului împreună cu 
nivelul de dezvoltare a abilităților fizice cresc în timpul procesului de pregătire (Jansone \& Vazne, 2009).

Un lucru benefic îl constituie aplicarea programelor de activitate fizică care să promoveze în rândul populației tinere, în special pe cele care afectează capacitatea de rezistență și flexibilitate a corpului. (Alonso-Fernández, GutiérrezSánchez \& Pino-Juste, 2012).

Determinarea unui fizic de invidiat ar trebui să fie ţelul fiecărui tânăr iar procesul de pregătire presupune stabilirea unor priorităţi pentru exercițiile compuse, de multe ori făcute tradiţional. Mediul social format din relaţii și valori sociale, influențează dirijarea tinerilor spre săli de fitness și formarea unor concepte privind opțiunea de a participa la modelarea condiției fizice. Efectele practicării activităților fizice conduc la beneficii privind asigurarea unei condiții fizice optime, dar și psihologice, în plan cognitiv, relație pozitivă evidențiată în unele studii efectuate de Fedewa and Ahn (2011), Keeley, and Fox (2009).

De asemenea, atributele personale precum stilul de viaţă, vârsta, sexul, statutul social-economic sunt alţi factori care pot avea valori morale şi estetice precum: autodepăşirea, tenacitatea, perseverenţa, vitalitatea, frumuseţea fizică, viabilitatea, echilibrul comportamental, cultul muncii, al angajării, etc. (Dobrescu, 2008a; Grosu, 2012).

În cadrul valorilor fizice apariţia interesului, dorinţei de realizare, a interrelaţiei umane între colegi sau cu antrenorul specialist, nu mai este un act pur dezinteresat. Forma deplină de existenţă şi dezvoltare a factorilor motivanți se regăseşte cel mai bine în cadrul conceptelor de pregătire ce facilitează stimularea autodepăşirii și de a atinge scopuri propuse în optimizarea condiției fizice. ”Pe langă abilitățile cognitive, motivația generală pentru performanță poate fi privită ca o a doua trasatură relevantă pentru succesul profesional". Uneori, moțivatia performanței este considerată a fi chiar cea mai importantă sursă a variantei performanței profesionale (Atkinson, 1978). Fitness-ul se realizează cu sine însuşi, cu stările de comoditate, cu diferitele şi variatele atracţii și ambiții în realizarea unei condiții fizice dorite care pot fi motivate de antrenori, instructori sau alți colegi mai experimentați.

Pornind de la premisele identificate, am ales elaborarea unui studiu privind percepția studenților din facultățile de profil, asupra interesului lor privind practicarea fitness-ului în aria curriculară a programului de Educație Fizică și Sportivă.

Consider că o abordare sociologică poate identifica repere importante privind grupele de motive și trebuințe ale studenților privind optimizarea condiției fizice prin mijloacele culturismului sau ale gimnasticii aerobice.

\section{Material și metode}

Problema motivaţiei studenţilor trebuie înţeleasă prin eforturile de a-i motiva într-o anumită direcţie cu atât mai semnificativ dacă relaţia profesor - student sau student - student este considerată una de colaborare, împărtăşind aceleaşi sentimente, obiective şi scopuri. Altfel, intervenţiile motivaţionale ce nu respectă 
convingerile unei persoane legate de practicarea unei discipline pentru optimizarea finess-ului pot produce efecte pe termen scurt și care pe o perioadă mai mare de timp pot să eşueze. Deşi se crede că obţinerea rezultatelor în fitness se datorează doar aptitudinilor înnăscute, trebuie să admitem că un rol determinant în atingerea obiectivelor propuse, îl constituie motivaţia studenților pentru pregătirea și participarea la disciplinele opționale de optimizare.

Plecând de la considerentul enunţat de Roşca (1966, p. 439) că fără cunoaşterea particularităţilor psihologice nu se poate organiza şi dirija percepţia, conduita, atenţia şi nici previziona gradul de înţelegere şi asimilare a unui proces instrucțional, am iniţiat acest studiu privind motivarea optimizării condiției fizice în cadrul procesului de formare a viitorilor formatori.

Scopul cercetării de faţă este de a realiza, prin aplicarea unui chestionar, identificarea elementelor care influenţează motivarea studenților în practicarea fitness-ului și descoperirea surselor de trebuinţe care acţionează cel mai bine asupra celor angrenaţi în această activitate.

În acest sens am organizat un studiu sociologic în perioada 2015 - 2017 pe un lot de 64 de studenți din anul II, studii de licență cu frecvență de la Facultatea de Științe ale Mișcării și Sportului și Sănătății din Bacău, programul Educație Fizică și Sportivă (EFS).

Cercetarea de față a plecat de la ipoteza potrivit căreia, identificarea ierarhiei în grupele de trebuinţe şi motive ale studenților de la EFS oferă posibilitatea orientării lor pentru optimizarea condiției fizice prin disciplinele opționale: culturism sau gimnastică aerobică.

Condiţiile de efectuare a cercetării au fost optime iar studenții anchetaţi au optat pentru a parcurge etapele cercetării, necondiționat.

Metodele de cercetare folosite au fost: documentarea bibliografică, observaţia, ancheta pe bază de chestionar, metoda statistico-matematică și grafică.

În realizarea acestui studiu am aplicat „chestionarul de motivaţie profesională" adaptat de Roco (2001, p. 214-215), după Bazin. Prin acest instrument validat, pot fi apreciate cât mai obiectiv trebuinţele şi motivele ce stau la baza participării conștiente a studenților la disciplinele ce vizează optimizarea condiţiei fizice, prin eşalonarea celor 35 de aserţiuni în ordinea importanţei acordate.

Tabelul 1. Grupe de motive și trebuințe

(adaptat de Roco după Bazin, prezentat în 2001, pag. 214-215)

\begin{tabular}{ccl}
\hline $\begin{array}{c}\text { Nr. Grupe } \\
\text { de trebuințe }\end{array}$ & $\begin{array}{c}\text { Nr. întrebărilor corespunzătoare } \\
\text { trebuințelor }\end{array}$ & \multicolumn{1}{c}{ Nume Grupe trebuințe } \\
\hline I. & $3,6,7,17,19,33,35$ & Fiziologice \\
II. & $1,9,16,18,22,31,34$ & Securitate \\
III. & $2,5,10,11,20,27,32$ & Contacte sociale (umane) \\
IV. & $4,8,13,21,23,24,29$ & Stimă, considerație \\
V. & $12,14,15,26,28,30,25$ & Realizare de sine (împlinire) \\
\hline
\end{tabular}


Punctele alocate de respondenţii cercetării pentru fiecare item au oferit posibilitatea valorizării motivelor încadrate în cele 5 grupe identificate de autori şi anume: trebuințe fiziologice, de securitate, contacte sociale umane, stimă, consideraţie şi realizare de sine (Tabel 1).

Conform acestui instrument de analiză sociologică, evaluările normative au condus spre efectuarea unor judecăţi de valoare şi aprecierea disponibilităţilor psihologice motivaţionale ale subiecţilor cercetării pentru desfășurarea unor discipline din categoria celor de influențare a fitness-ului.

\section{Rezultate și discuții}

Pentru a sublinia trebuinţele şi motivele ce stau la baza manifestării grupului ţintă, rezultatele obţinute la cele 5 grupe au fost interpretate ţinând cont de valoarea medie, maximă şi minimă raportată la nivelul grupului (Tabel 2, Fig. 1).

Tabelul 2. Centralizator al rezultatelor statistice ale grupului ţintă la chestionarul de motivaţie

\begin{tabular}{lccccc}
\hline \multirow{2}{*}{ Indicatori statistici } & \multicolumn{5}{c}{ Grupe de motive şi trebuinţe } \\
\cline { 2 - 6 } & Fz & Cs & Rs & S & Sc \\
\hline Media aritmetica & 106.17 & 113.76 & 129.45 & 138.43 & 142.18 \\
Abaterea standard & 23.95 & 22.49 & 21.70 & 22.69 & 32.11 \\
Valoarea maximă & 164 & 152 & 163 & 181 & 188 \\
Valoarea minimă & 72 & 65 & 96 & 102 & 73 \\
\hline
\end{tabular}

Legendă: Fiziologie (Fz), Contacte sociale umane (Cs), Realizare de sine (Rs), Securitate (S), Stimă, consideraţie (Sc).

Analiza rezultatelor obţinute la cele 5 grupe de trebuinţe şi motive ce au fost identificate la baza percepției grupului ţintă, au fost interpretate ţinând cont de valoarea maximă, medie, şi minimă raportată la nivelul grupului.

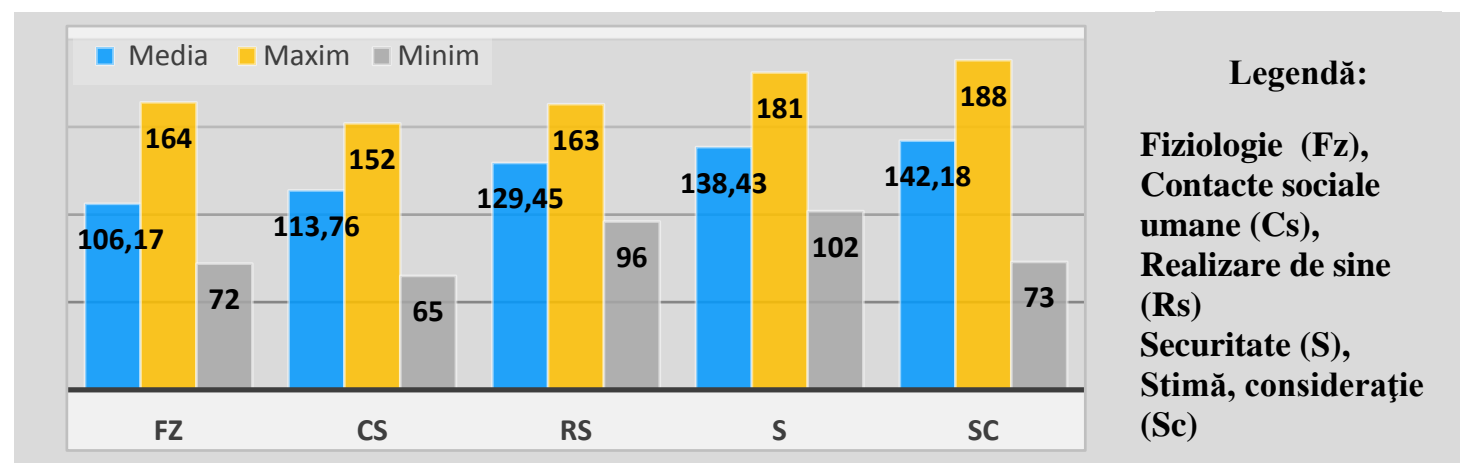

Figura 1. Rezultatele abaterii standard ale motivaţiei pe grupe de trebuințe 
Abaterea standard (Tabel 2, Fig. 2) la nivelul celor 5 grupe de motive identificate a înregistrat valori cuprinse între 32.11 (Sc) şi 21.70 (Rs) valori ce le considerăm mari şi demonstrează un grad de omogenitate scăzut al colectivului anchetat, aspect normal.

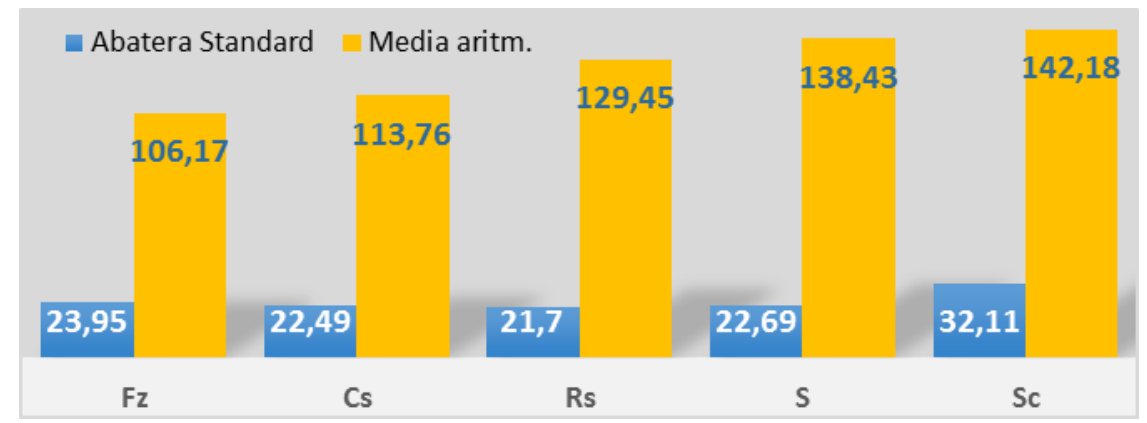

Figura 2. Rezultatele abaterii standard ale motivaţiei pe grupe de trebuințe

Grupa de motive şi trebuinţe de ordin fiziologic s-a situat în topul preferinţelor studenților anchetaţi, cu o mede aritmetică de 106.17 pct., cu valoarea cea mai mică de 72 pct. şi cea maximă de 164 pct. (Tabel 2, Fig. 1.) Diferenţă dintre medie şi valoarea minimă (34.17 pct.) este considerabil mai mică decât cea dintre valoarea maximă şi medie (57.82 pct).

Motivele de tip fiziologic se situează pe prima poziţie și punctajele cele mai mici de la aceşti itemi demonstrează că pentru respondenții cercetării efectele morfo-funcționale ale activităților de tip fitness pentru optimizarea condiției fizice sunt prioritare.

La evaluarea acestei grupe de tendințe au fost luate în valoare rolul programelor de instruire raționalizate și riguroase de lucru, avantajele privind dozarea efortului și posibilitatea de a le alterna cu perioadele de repaus. În cadrul acestui acest grup de motive se adaugă aprecierea condiţiilor materiale bune pentru lucru, atractivitatea programelor de pregătire prin asigurarea cadrului tehnic și de depășire a propriilor eforturi. De asemenea sunt conștientizate efectele acestor programe asupra optimizării condiției fizice, a influențelor parametrilor funcționali, a modelării corporale în plan morfologic, aspecte utile valorificării lor în cariera viitorilor formatori în domeniu.

Abaterea standard (Fig. 2) la nivelul acestei grupe de motive identificate a înregistrat valoarea de 23.15 ceea ce demonstrează un grad de omogenitate scăzut al grupului țintă.

În ordinea valorică a ierarhiei motivele identificate s-au situat cele ce privesc contactele sociale umane cu o valoare medie de 113.76 pct., o maximă de 152 pct. şi o minimă de 65 pct. Diferenţa dintre medie şi valoarea minimă de 48.76 pct. este mai mare decât cea dintre valoarea maximă şi medie de 38.23 pct. (Tabel 2, Fig. 1).

Putem afirma că pentru studenții din eșantionul studiat contează cadrul social, al resurselor umane din timpul pregătirii cu implicaţii în modificarea şi 
adaptarea permanentă la situaţiile mereu schimbătoare, la colectivitatea și mediul de lucru.

Aceste rezultate demonstrează că tinerii din grupul țintă, apreciază formarea spiritului de colaborare, comunicare și înţelegere cu ceilalţi colegi create pe parcursul antrenamentelor de culturism sau a ședințelor de gimnastică aerobică, aspect deosebit de important în procesul de pregătire și formare profesională. Însumând și alte aserţiuni din această grupă de motive, rezultă că subiecţii cercetării apreciază instituția destinată instruirii, cu o imagine și un prestigiu dobândit prin calitatea procesului formativ a absolvenților în domeniu. De asemenea respondenții sunt motivați de prezența specialiștilor care coordonează disciplinele în curricula universitară, competenți, profesioniști, cu recunoaștere națională. Ei percep deopotrivă importanța participării la aceste forme de fitness prin influența celorlalți participanți care determină trecerea barierelor unui efort de intensitate.

Abaterea standard (Fig. 2) la nivelul acestei grupe de motive identificate a înregistrat valoarea de 26.28 ceea ce demonstrează un grad de omogenitate scăzut al colectivului anchetat.

Pe locul trei în preferințele studenților anchetați se situează grupa ce vizează realizarea de sine cu o valoare medie de 129.45 pct., o valoare maximă de 163 pct. şi minimă de 96 pct. (Tabel 2, Fig. 1). Diferenţa dintre valoarea minimă şi medie (33.45 pct.) este sensibil mai mică decât cea dintre medie şi valoarea maximă (33.54 pct.), observându-se o tendinţă spre cea medie.

Această poziție în cadrul celor 5 grupe de motive susţine percepția studenţilor asupra rolului de creativitate şi adaptare în cadrul activităţilor de pregătire. Ei doresc să-şi exercite dorința de optimizare a fitness-ului în condițiile asumării responsabilităţii în ceea ce fac, fiind capabili să aprecieze posibilităţile de stimulare a interesului intrinsec, ale unei autoevaluări și aprecieri a propriilor activități. Respondenții sunt convinși de importanța obiectivelor curriculale de îndeplinit şi apreciază oportunităţile pentru o activitate responsabilă ce implică stimularea efortului, creșterea capacității de efort și dezvoltarea personalității.

Abaterea standard (Fig. 2) la nivelul acestei grupe de motive identificate a înregistrat valoarea de 18.94 ceea ce demonstrează cel mai mare grad de omogenitate la nivelul colectivului anchetat.

Grupa motivelor derivate din nevoia de securitate reprezintă o importanţă mai mică între motivaţiile tinerilor investigați, înregistrând o valoarea medie de 138.43 pct., una maximă de 181 pct. şi minimă de 102 pct. (Tabel 2, Fig. 1) Diferenţa dintre medie şi valoarea minimă de 35.3 puncte este mai mică comparativ cu cea dintre valoarea maximă şi medie de 43.56 pct.

Potrivit acestei grupe de trebuințe, respondenții chestionați manifestă reținere pentru o activitate de lucru impusă, pentru siguranța din sala de lucru şi posibilitatea unei îndrumări nemijlocite şi permanente. Activitatea de pregătire nu este apreciată la valoarea în care pot oricând să fie apți pentru o autoconducere a antrenamentului pe baza cunoștințelor și a deprinderilor însușite. 
Abaterea standard (Fig. 2) la nivelul acestei grupe de motive a înregistrat valoarea de 26.31 ceea ce demonstrează un grad de omogenitate scăzut la nivelul subiecților.

Pe ultimul loc se situează grupa ce vizează motivele privind formarea trăsăturilor de stimă şi consideraţie cu o valoare medie de 142.18 pct., o valoare maximă de 188 pct. şi minimă de 73 pct.. (Tabel 2, Fig. 1) având o diferenţa dintre medie şi valoarea minimă (69.18 pct.) mai mare decât ceea dintre valoarea maximă şi medie (45.81 pct.).

Din aserţiunile bifate se desprinde concluzia că studenții anchetați nu sunt preocupați de posibilitatea de a desfăşura o activitate de pregătire de calitate, cu sarcini clar definite și care le solicită o atenție ridicată. Sunt reticenți la indicațiile primite privind pregătirea optimizată a condiției fizice care nu le dă sentimentul utilităţii, aprecierii juste a efortului depus. În același timp, potrivit acestei grupe de trebuințe, sunt exprimate motive de a nu avea bucuria libertății și independenței în a desfășura o activitate motrică preferată.

Abaterea standard (Fig. 2) la nivelul acestei grupe de motive a înregistrat valoarea de 38.21 ceea ce demonstrează cel mai mic grad de omogenitate la nivelul grupului de studenți anchetaţi.

\section{Discuții}

Înţelegerea structurii psihice a respondenților prin prisma surselor care îi pot motiva cel mai bine în practicarea celor două discipline de fitness, creează posibilitatea optării pe baza creşterii motivaţiei pentru participarea la programele de pregătire și mărirea interesului pentru îmbunătățirea condiției fizice. Motivele de tip fiziologic se situează pe prima poziţie şi demonstrează că pentru respondenţii cercetării efectele morfo-funcționale ale procesului de pregătire din sală sunt prioritare, apreciind condiţiilor materiale bune pentru lucru, atractivitatea antrenamentelor / ședințelor prin asigurarea unor alternative dinamice și favorizarea depășirii propriilor eforturi.

În urma rezultatelor finale ale cercetării există probabilitatea exprimării opțiunilor d. p.d.v. motivațional ale studenților din anul II spre ambele discipline cu scop fundamental în optimizarea condiției fizice. Certitudinea acestei supoziţii poate fi însă influențată și de alti factori subiectivi.

Într-un studiu efectuat de Parish and Treasure (2003) au fost urmărite percepțiile climatului motivațional și a capacității asupra motivației situaţionale privind comportamentul față de activitatea fizică la elevi. Rezultatele unei analize de regresie ierarhică au relevat genul, capacitatea percepută și percepțiile climatului de stăpânire explicând o cantitate semnificativă de variație a activității fizice. Autorii sugerează că promovarea unui climat motivațional în educația fizică orientat pe stăpânire va stimula motivația situațională determinată de sine și de activitatea fizică.

In identificarea motivațiilor și importanța percepută a anumitor factori de participare la disciplina arte marțiale din Marea Britanie, rezultatele au indicat următoarea ordine în funcție de trebuințele și motivele exprimate: 1-afiliere; 2- 
prietenie; 3-fitness; 4-recompensă / status; 5 competiție; 6-dezvoltare situațională și 7-dezvoltarea aptitudinilor. (Jones, Mackay, \& Peters, 2006).

Politicile orientate spre creșterea numărului de ore și asigurarea unor condiții optime pentru desfășurarea educaţiei fizice în școli au existat unele proiecte comunitare care au constituit factori importanți în crearea unor condiții favorabile de infrastructură, oferind accesibilitate din punct de vedere organizatoric. Cercetând acest fenomen, Solmon (2015) subliniază că aceste tendințe nu sunt suficiente pentru a soluţiona problemele legate de inactivitatea fizică a copiilor și tinerilor. Trebuie luați în considerare factorii psihologici, care influențează orientarea preocupările și decizia lor de a fi activi fizic. Este esențial ca specialiștii domeniului activităţilor corporale să determine convingeri și motivații privind importanța programelor de fitness, a efectelor benefice ale acestora asupra sănătătii, promovarea unui stil de viaţă activ la nivelul copiilor și a adolescenților.

\section{Concluzii}

În încercarea de a găsi cele mai bune variante de a determina ce îi motivează pe studenții anchetaţi, considerăm că această cercetare constituie o contribuţie importantă în identificarea motivației acestora pentru optimizarea a condiției fizice, utilă formării lor ca viitori specialiști.

Aceste rezultate demonstrează că studnții din anul II EFS sunt conștienți de rolul activităților din cadrul pregătirii musculare de dezvoltarea spiritului de colaborare, comunicare și înţelegere cu cei din jur, fiind convinși de efectele calităților de socializare și relaționare în viața de zi cu zi și în viitoarea carieră.

În cadrul celor 5 grupe de motive şi trebuinţe se indentifică percepția respondenților privind aprecierea posibilităţile de stimulare ale interesului, a rolului de creativitate şi adaptare în cadrul pregătirii, a unei evaluări și aprecieri a depășirii propriilor eforturi.

Ei sunt convinși de importanța obiectivelor curriculare propuse prin fișa disciplinei şi apreciază oportunităţile pentru o activitate responsabilă ce implică stimularea efortului, creșterea capacității de lucru și dezvoltarea personalității.

În urma analizei şi a interpretării rezultatelor obţinute se constată că ipoteza lucrării a fost confirmată drept pentru care afirmăm că identificarea ierarhiei grupelor de trebuinţe şi motive ale studenților din anul II EFS oferă posibilitatea orientării preocupărilor pentru optimizarea condiției fizice prin disciplinele opționale oferite de curricula universitară. 